\title{
A AUTONOMIA DA VONTADE E O FENÔMENO DO SUPERENDIVIDAMENTO NOS CONTRATOS BANCÁRIOS
}

\author{
Barbara Candido de Araújo \\ Universidade do Oeste Paulista - UNOESTE, curso de Direito, Presidente Prudente, SP. E-mail: \\ barbaracandido7@outlook.com
}

\section{RESUMO}

As contratações bancárias, por vezes, geram conflitos de interesses, motivados pelo excesso de débitos lançados às pessoas físicas envolvidas na transação. Para solver as lides, os interessados socorrem-se das vias judiciais, apresentando ao terceiro poder o quão impraticável são os juros e os descontos da instituição financeira. No polo oposto, o argumento se baseia na lei que o contrato forma entre as partes e, ainda, na reverenciada liberdade de contratação. Frente à tão contraditórias alegações, a proposta é trazer possíveis desfechos a tais demandas, sem, no entanto, esgotar o tema, ultrapassando o respeitado e tradicional pensamento contratualista, em determinados momentos. Contudo, noutros, ressalvando a segurança dos acordos e defendendo, portanto, o outro polo da ação. Como trivialmente ocorre no Direito, o resultado dependerá da análise do caso concreto, adotando-se ora um posicionamento e, na sequência, outro.

Palavras-chave: Autonomia da vontade; Contratos bancários; Instituições financeiras; Superendividamento; Dignidade da pessoa humana.

\section{INTRODUÇÃO}

A moeda é a ferramenta de troca da sociedade moderna. Até o mais entusiasta socialista, não consegue sobreviver sem ela. Desde os primórdios, é sabido que a riqueza de alguns, majoritariamente, vinha acompanhada da desventura de outros, como o foi na exploração das terras brasileiras e nos séculos de escravidão.

Atualmente, as correntes não são físicas. Quando as dívidas patrimoniais deixaram de gerar punições corporais (ou até, prisão) ao mau pagador - salvo as alimentícias (Art. 5o, inciso LXVII da CF) - por elas, começaram a responder os bens do devedor e a sua imagem pública, no que tange ao registro no cadastro de inadimplentes.

Ocorre que o aumento dos débitos, tem levado consumidores a privação de elementos básicos a sua existência, ou, ao menos diminuído a qualidade de vida dos mesmos. Vindo novamente a ofender a dignidade da pessoa humana, outrora através das agressões físicas, hoje, por meio das restrições impostas.

Antagonicamente, as instituições financeiras respaldam suas cobranças no direito que emergiu do contrato, firmado, segundo elas, pela livre disposição do contraente. Seria o modelo contratual capaz de desconsiderar os direitos, até então, conquistados? O contrato é intransponível?

Assim, o presente estudo pretende apresentar o problema e sugerir alternativas para resolvê-lo, baseadas em doutrinas e jurisprudências vigentes, contudo, não admitindo a falácia de pressupor sua exaustão. Por fim, cabe elencar que trata-se de uma pesquisa bibliográfica, utilizando o método dedutivo de pesquisa, qual seja, a análise da amplitude à concentração (premissa maior à menor). 


\section{CRÉDITO: FUNÇÃO E DISFUNÇÃO}

As instituições financeiras são responsáveis pela transferência de recursos dos agentes superavitários (investidores) aos deficitários (aqueles que necessitam de crédito), obtendo lucratividade pelo spread - diferença existente entre os juros cobrados nas concessões e a rentabilidade paga aos poupadores.

A implantação do Plano Real reduziu exponencialmente a inflação noutro momento observada por aqui, com isto, houve grande incentivo ao consumo, o que, por sua vez, fomentara o crédito.

O derradeiro possui importante papel no crescimento da economia, alocando recursos no mercado, o que não aconteceria se a pecúnia continuasse com o poupador que, por suas características, optou por restringir seu consumo e cumular capital.

Funciona ainda como fator de inclusão social, pois fornece oportunidades anteriormente impensadas aos beneficiários, dando acesso a bens de consumo de primeira necessidade (geladeira) e a outros, não fundamentais, mas que corroboram com a qualidade de vida do cidadão, um exemplo é o lazer, outro direito constitucional.

Todavia, também transparece o lado opressor do crédito e, até, simboliza um meio de exclusão social se fruído sem moderação, exemplo: quando as finanças estão descontroladas, o titular deixa de frequentar os lugares onde habitualmente ia, se desfaz do patrimônio e de despesas dispensáveis, dentre outras influencias negativas. Schonblum (2015), bem define: "O crédito pode ser a 'salvação da lavoura' ou o 'empurrãozinho na beira do precipício'”.

Os consumidores seduzidos pela facilidade no acesso a esses recursos - tais como empréstimos pessoais, limite de cheque especial, cartões de crédito, etc. - e levados pela cultura globalizada materialista, passaram a utilizá-los de modo nocivo. Nas palavras de Schonblum (2015):

Tudo é muito acelerado pela publicidade/marketing (merchandising, emails, spams, cookies etc.), fazendo que, além da oferta de produtos e serviços que não eram (obrigatoriamente) consumidos em tempos pretéritos (plano de saúde, celulares, Internet, academia, TV a cabo etc.), as famílias passassem a ter mais desejos e necessidades consumistas, que se tornam possíveis através da farta concessão de crédito (empréstimos direto no caixa eletrônico, bankfone, internetbank, "pastinhas", crédito consignado etc.).

O resultado logo aparecera. Grande número de pessoas deixaram ou tendem a deixar de arcar com as dívidas e, em casos extremos, até de suportar os gastos essenciais à subsistência de sua família.

Pesquisas afirmam que o Brasil figura dentre as nações com o maior juros bancários do mundo, fato justificado por diversos fatores. A problematização que motivou o presente estudo, questiona a validade das reiteradas ações que protestam os descontos ditos abusivos dos contratos firmados com os bancos.

Analisando inicialmente as provocações, coincide o histórico que resultou na inadimplência: contratos sequenciais, sendo novos ou renovados. Por óbvio a insolvência fora construída, em regra, no decorrer de um período pela procura ou oferecimento sucessivo do crédito.

Quanto à responsabilidade do banco na somatória de dívidas, cumpre narrar que a instituição tem o dever de zelar pela concessão consciente, como uma concessão defensiva, ou seja, liberando somente aquilo que se mostra plausível, não retirando a possibilidade de 
pagamento do devedor. Este posicionamento é positivo inclusive para a instituição bancária, que não verá seus índices de inadimplência avançarem, o que pontua de forma negativa a mesma.

A adoção dessa conduta demonstra que a boa-fé fora empregada naquela pactuação, como é esperado pelo Direito utópico, ensejando, inclusive, os ganhos de causa ou a procedência parcial frente às oposições do cliente bancário.

Por outro lado, a defesa dos bancos se restringe a trazer argumento, de não inferior significado, afirmando que o autor da ação teve acesso ao contrato e mediante sua assinatura, concordou com as previsões ali reguladas. Portanto, aflora a discussão: a mera concordância pretérita legitima o inviável desconto atual? Mormente, pela modalidade do contrato assinado não permitir a discussão sobre suas cláusulas.

Ou ainda, o prejudicado dispôs da autonomia de sua vontade, logo, não pode refutar tal postura?

O debate aqui travado apresenta tão considerável relevância que os legisladores já o disciplinavam tanto no Decreto-Lei 22.626 de 1933, quanto no texto constitucional de 1934, com as redações que seguem, respectivamente:

Art. 11. O contrato celebrado com infração desta lei é nulo de pleno direito, ficando assegurado ao devedor a repetição do que houver pago a mais.

Art. 13. É considerado delito de usura, toda a simulação ou prática tendente a ocultar a verdadeira taxa do juro ou a fraudar os dispositivos desta lei, para o fim de sujeitar o devedor a maiores prestações ou encargos, além dos estabelecidos no respectivo título ou instrumento.

Art. 15. São consideradas circunstâncias agravantes o fato de, para conseguir aceitação de exigências contrárias a esta lei, valer-se o credor da inexperiência ou das paixões do menor, ou da deficiência ou doença mental de alguém, ainda que não esteja interdito, ou de circunstâncias aflitivas em que se encontre o devedor.

No que concerne à decorrida Constituição:

Art. 117 - A lei promoverá o fomento da economia popular, o desenvolvimento do crédito e a nacionalização progressiva dos bancos de depósito. Igualmente providenciará sobre a nacionalização das empresas de seguros em todas as suas modalidades, devendo constituir-se em sociedade brasileira as estrangeiras que atualmente operam no país.

Parágrafo único. É proibida a usura, que será punida na forma da lei.

Partindo da "letra fria" de lei apresentada, alguns esclarecimentos são oportunos. A leitura do Decreto-Lei ainda vigente com o destaque dos artigos anteriores traz nas entrelinhas, além da vedação da "remuneração exagerada impedindo o desenvolvimento das classes produtoras", como prevê o próprio preâmbulo, a busca pela transparência nas relações financeiras e a punição da má-fé.

Outro ponto a ser evidenciado está na expressão "circunstâncias aflitivas" disposta no artigo 15. Afiguraria essas circunstâncias, num estado psíquico de insegurança, angústia ou aflição, 
portanto, se deduz que a carência de elementos primordiais - como alimentos, roupas, manutenção da habitação - e, a urgência na execução de algo - como tratamentos médicos e a compra de medicamentos, estariam contemplados na classificação ressaltada. Enfim, é defeso aproveitar-se da vulnerabilidade do cliente pela situação extrema em que ele se encontra.

Quanto ao artigo constitucional, vale esmiuçar o contexto em que ele foi gestado. $\mathrm{Na}$ década de 30, o país passava por uma fase de inconstância, tanto econômica, devido à Crise de 1929, que ocasionou a queda do setor cafeeiro - a principal comódite da época - quanto política, pela inviabilidade do processo eleitoral fundado no coronelismo e na não aceitação do resultado das eleições pelos vencidos sobre o amparo do regime do Café com Leite. Ainda, emergiam, conforme elencado por Pinho (2014, p. 196), "novas questões sociais e econômicas decorrentes do processo de urbanização e industrialização e de reivindicações político-econômicas de uma nova classe social: o operariado". Com isto, a Carta Magna de 1934 repudiou o singelo ideal de liberdade, puro e simples, pregando a intervenção do Estado na economia.

Dadas as presentes considerações, subentende-se por usura, a forma de enriquecimento indevido pelo lucro exorbitante obtido em operações de crédito. Cunha (2011, p. 290 - 291) assim define:

Usura pecuniária - 1. Remuneração excessiva do capital (Ivc). 2. Empréstimo de dinheiro mediante a cobrança de juros elevados. 3. Crime consistente em cobrar juros superiores à taxa legal (LU; CPM 267; L 1.521/1951, 4o-a; L 7.492/1986, 80).

Usura real - Crime consistente em obter ou estipular em qualquer contrato, abusando da premente necessidade, inexperiência ou leviandade da outra parte, lucro patrimonial que exceda o quinto do valor corrente ou justo da prestação feita ou prometida (L 1.521/1951, 4o-b). v. lesão.

Especialmente o segundo conceito, qual seja, Usura Real, repisa assunto já tratado, sendo o inverso do que se espera de uma contratação pautada na boa-fé.

Ora, a partir de uma abordagem superficial, tem-se que os bancos sobrevivem mediante os juros e encargos que recolhem e, diferente do posicionamento de São Tomás de Aquino, o qual

[...] era contrário ao recebimento de juros nos empréstimos, pois defendia que o dinheiro não era consumido durante o mútuo, ou seja, se fosse integralmente devolvido, nada mais deveria ser acrescido à quantia tomada, sob pena de ser classificado como usura. (CÁRNIO, 2010, p. 94)

...não deseja este estudo confrontar a atividade ou remuneração pelos serviços bancários, de outro modo, o objetivo é sugerir tratamentos aos impasses.

A hodierna Constituição de 1988 reforça em seu artigo 21, que é de competência da União "fiscalizar as operações de natureza financeira, especialmente as de crédito" Machado (2015, p. 138) explica a preocupação:

Justifica-se esta competência atribuída à União pelo caráter nacional dos interesses em questão, já que as operações financeiras e a poupança popular são essenciais à economia nacional. A fiscalização que a União deve exercer recai sobre todas as operações de natureza financeira, sendo 
destacadas algumas no texto constitucional. Mas o texto é claro ao indicar todas as operações de natureza financeira como submetidas à fiscalização.

A elaboração da Carta Magna de forma analítica, permitiu que a mesma se desvinculasse do conteúdo meramente estrutural do Estado, trazendo direcionamentos de caráter social, como aqueles ligados à economia.

Para algumas famílias, o acesso às linhas de crédito se tornou sedutor ao ponto de estabelecer relação de dependência, sem as quais, não se pode sustentar o orçamento. Surgira, então, a urgência de desconstruir o ideal de intangibilidade dos contratos bancários, reconhecendo-se que eles perdem a efetividade quando o estado anteriormente observado, não se repete no momento corrente, modificando e muito, os reflexos das prestações a serem realizadas.

\section{A AUTONOMIA DA VONTADE VERSUS ONEROSIDADE EXCESSIVA}

Antes de adentrar às características do instrumento, é válido traçar um panorama sobre o mesmo. Os contratos estabelecem relações obrigacionais vinculando duas partes a determinada prestação. Diferenciam-se do Direito Real, pois o último define a interligação de um sujeito à uma res. Tartuce (2015, p. 1) assim explanou:

O contrato é um ato jurídico bilateral, dependente de pelo menos duas declarações de vontade, cujo objetivo é a criação, a alteração ou até mesmo a extinção de direitos e deveres de conteúdo patrimonial. Os contratos são, em suma, todos os tipos de convenções ou estipulações que possam ser criadas pelo acordo de vontades e por outros fatores acessórios. Dentro desse contexto, o contrato é um ato jurídico em sentido amplo, em que há o elemento norteador da vontade humana que pretende um objetivo de cunho patrimonial (ato jurígeno); constitui um negócio jurídico por excelência.

Assim sendo, o ato de contratar reflete a manifestação do direito à liberdade, sendo moldado por vários princípios, dentre eles, o da autonomia da vontade e da boa-fé, sem a qual, parafraseando Tartuce $(2015$, p.1) não existe contrato: "Para existir o contrato, seu objeto ou conteúdo deve ser lícito, não podendo contrariar o ordenamento jurídico, a boa-fé, a sua função social e econômica e os bons costumes".

Já sobre a autonomia da vontade, Schonblum (2015) indica:

[...] centra-se no ideal da liberdade que possuem as pessoas capazes para poder contratar como desejarem, devendo responder, todavia, pelos encargos necessários para que sejam as contraprestações adimplidas.

Os instrumentos contratuais surgiram como forma de assegurar aquelas obrigações que dantes eram fixadas através da via oral, mas que, com o tempo, se mostraram ineficazes.

A classificação de um contrato na esfera bancária se dá quando uma das partes é o banco e a outra o cliente, estando elas ligadas por um serviço ou produto. Considerando a disparidade envolvida na transação, a proteção pelo Código de Defesa do Consumidor é viável, pois o então fornecedor, costumeiramente, figurará em lides judiciais, diferente do consumidor, que, em regra, se refutará a postular. 
Desde o princípio, ficara estipulado que o contrato faria lei entre as partes, conforme o reiterado brocardo latim preceitua: pacta sunt servanda. Mas com a evolução social, ficou nítido que tal premissa era relativa, posto que se o contrato continuasse "intocável", para um dos contraentes, ele poderia vir a ser demasiadamente injusto...

Modernamente, minorando um pouco a onda do dirigismo contratual, a lei reconheceu que a autonomia de vontade será restringida apenas quando em confronto com os preceitos da ordem pública e dos bons costumes, inquinando de nulidade os contratos que assim dispuserem [...] (Schonblum, 2015)

Doutrinadores passaram a defender que se houvesse alteração no status quo ante não poderiam ser mantidos os termos do contrato, posto que, por situação imprevisível ou incontrolável, o devedor estaria impossibilitado de realizar a prestação devida, sendo fundamental, a intervenção do juízo imparcial para reestabelecer o equilíbrio da relação.

A priori parece um contrassenso o envolvimento do Estado num ato essencialmente privado, onde as partes acordaram as cláusulas por meio da livre disposição (a conhecida: autonomia da vontade). Porém a história exemplificou que a liberdade desmedida poderia ser a origem do caos, ensejando a coerente intervenção pública.

Há o desvirtuamento sobreposto, quando por fato futuro as condições pré-estipuladas são modificadas prejudicialmente. Lôbo (2015, p. 20) abordando o eventual acidente que possa ocorrer no decorrer do contrato, defende como tratá-lo por meio dos princípios:

Talvez uma das maiores características do contrato, na atualidade, seja o crescimento do princípio da equivalência material das prestações, que perpassa todos os fundamentos constitucionais a ele aplicáveis. Esse princípio preserva a equação e o justo equilíbrio contratual, seja para manter a proporcionalidade inicial dos direitos e obrigações, seja para corrigir os desequilíbrios supervenientes, pouco importando que as mudanças de circunstâncias pudessem ser previsíveis. O que interessa não é mais a exigência cega de cumprimento do contrato, da forma como foi assinado ou celebrado, mas se sua execução não acarreta vantagem excessiva para uma das partes e desvantagem excessiva para outra, aferível objetivamente, segundo as regras da experiência ordinária. Esse princípio conjuga-se com os princípios da boa-fé objetiva e o da função social, igualmente referidos no Código Civil.

Assim, o contrato não finda com sua transcrição, ele se modifica constantemente visando atingir fim comum às partes, alcançando o objetivo sem que haja onerosidade excessiva a elas. Entende-se por onerosidade excessiva:

Em linhas gerais, a cláusula, tida como implícita nos contratos, teria como essência a lógica de que, nos pactos compostos de obrigações sucessivas ou a serem cumpridas no futuro, o efetivo cumprimento estaria condicionado à manutenção das condições de fato contemporâneas à formação do vínculo. Assim, caso houvesse alterações de fato entre a 
contratação e o cumprimento, a parte excessivamente onerada poderia exonerar-se de sua obrigação. (NASSER, 2011, p. 109 - 110)

O combate enfatizado busca coibir a inclinação da balança contratual para um dos lados em nítido e desproporcional desfavor do outro.

Deste modo, emerge o entendimento de que a dignidade da pessoa humana se sobressai em qualquer situação, sendo "a razão de ser do Direito". Pois, é conhecida a função desse de intermediar conflitos, buscando o que é justo à coletividade, sem a qual, o primeiro desaparece.

Apesar de ser um tema controvertido, parece bastante aceitável, a decisão pela sobrevivência honrada de uma família (lato sensu, logo, sendo considerado também o indivíduo solteiro como unidade familiar) frente aos lucros auferidos pelo credor com o cumprimento imediato do pactuado.

Com isto, revelara-se a função social do contrato superando o direito militado pelos franceses à propriedade, que com a evolução, mostrara-se insuficiente. $O$ domínio da res não pode vir acompanhado da mera satisfação dos desejos do titular, podendo, se deste modo o fosse, implicar no abuso de direito (art. 187 do Código Civil). O ditado popular de autor desconhecido clareia e limita os atos do dono: "seu direito acaba onde começa o dos outros".

Assim, a conquista do direito de propriedade tão enfatizada na Revolução de 1789 não está "acabada". Com a evolução da sociedade, e, por consequência, do Direito, o contrato ganhara complexidade e conotação social. Foram considerados os quocientes da operação, demonstrando que havia uma vastidão de princípios a serem considerados na composição e execução do acordo, colaborando com a aspiração de justiça. No mesmo sentido, Lôbo (2015, p. 19)

A Constituição Federal brasileira apenas admite o contrato que realiza a função social, a ela condicionando os interesses individuais, e que considera a desigualdade material das partes. O Código Civil de 2002, em viragem completa, introduz a regulamentação geral dos contratos com o princípio da função social, determinante do conteúdo e dos limites da liberdade contratual. Com efeito, a ordem econômica tem por finalidade "assegurar a todos existência digna, conforme os ditames da justiça social" (art. $170 \mathrm{da}$ CF). A justiça social importa "reduzir as desigualdades sociais e regionais" (art. 3o e e inciso VII do art. 170 da CF).

Ainda, cumpre explanar que outro pilar da supracitada revolução foi relativizado: a liberdade. Antes, imaginava-se que a positivação desse direito resolveria os infortúnios pelo simples desprendimento ou retirada do indivíduo da égide do Estado Leviatã. Entretanto, essa visão tomou contorno equivocado, pois os sujeitos do Direito não são iguais e, a liberdade incontestável só substituiu o poder estatal pelo poder dos mais fortes, ou ricos (aristocracia).

Com o tempo, instaurou-se o Estado Democrático, onde há a intervenção do Poder Público com o intuito de equiparar os obrigados, prevenindo o injusto.

Conclui-se, apenas pelo princípio acima elencado, que o contrato não é absoluto e, em vista disto, as lides envolvendo o assunto preconizado já gozariam de razoabilidade.

Existe também, quem discorde dessa premissa da "autonomia da vontade" na sociedade de consumo, pois pelos padrões impostos e a manipulação publicitária, inconscientemente os consumidores são pressionados a agir de certa maneira. Complementando o raciocínio, deve ser destacado que especificamente nos contratos bancários, há preponderância da assinatura em modelos de adesão, ou seja, o polo vulnerável não pode alterar a maioria das disposições 
presentes no instrumento. Segue o dispositivo da Lei 8.078 de 1990 - Código de Defesa do Consumidor, que o conceitua:

Art. 54. Contrato de adesão é aquele cujas cláusulas tenham sido aprovadas pela autoridade competente ou estabelecidas unilateralmente pelo fornecedor de produtos ou serviços, sem que o consumidor possa discutir ou modificar substancialmente seu conteúdo.

Schonblum (2015) assim o interpretou:

Os contratos de adesão seriam, então, mera forma de contratar, criada para que fossem acelerados os negócios jurídicos em tempos de tecnologia avançada, extinguindo, com isso, a fase pré-negocial e restringindo a autonomia de vontade, por serem pré-redigidos pelo fornecedor de serviços ou bens, com cláusulas rígidas, gerais e abstratas.

Ademais, critica-se a tal liberalidade perante a urgência ou necessidade que os consumidores tem de desfrutar do objeto do trato.

Em certas áreas, as condições gerais dos contratos podem alcançar números gigantescos de destinatários, como se dá com os planos de saúde. Nessas situações, o consentimento livre é substituído por uma relação de poder e submissão. A legislação contratual clássica é incapaz de enfrentar adequadamente esses problemas, o que torna imperiosa a concretização dos princípios constitucionais aplicáveis à atividade econômica, voltados à proteção dos contratantes vulneráveis. (LÔBO, 2015, p. 21)

Portanto, não são os componentes da relação considerados inimigos ou dissidentes, mas sim, colaboradores de um propósito uno. E, por óbvio não há compatibilidade entre a função social do contrato e a exposição de uma família a precariedade, à privação do mínimo existencial. Certamente, não era este o fim desejado pelos contratantes, consequentemente, não há que se falar na manutenção daquilo que anteriormente ficou firmado.

\section{SUPERENDIVIDAMENTO: A PRINCIPIOLOGIA COMO ALTERNATIVA ÀS LACUNAS LEGAIS}

É sabido que inúmeros consumidores por desregramento pessoal ou por imprevisto, têm suas finanças descontroladas, podendo ocasionar a inadimplência generalizada ou o fenômeno econômico, social e jurídico nomeado: superendividamento.

Conceituou Schonblum (2015): [...] "pode ser definido como a impossibilidade global de o devedor pessoa física, consumidor leigo e de boa-fé, de pagar todas as suas dívidas atuais e futuras de consumo".

Enriquecendo o transcrito, Marques (2010) apud Schonblum (2015) traz:

o superendividamento é um estado da pessoa física leiga (o não profissional ou o não empresário, que pode falir), um devedor de crédito que o contraiu de boa-fé, mas que agora se encontra em uma situação de impossibilidade (subjetiva) global (universal e não passageira) de pagar todas as suas dívidas atuais (já exigíveis) e futuras (que vão vencer) de 
consumo com a sua renda e patrimônio (ativo) por um tempo razoável (a indicar que teria de fazer um esforço por longos anos, quase uma escravidão ou hipoteca do futuro, para poder pagar suas dívidas).

No tocante às concessões bancárias, ganha importância a análise do crédito Consignado por ser este um dos vilões do endividamento, tendo aclarado seu lado negativo pela constante exposição no Judiciário. Diferencia-se dos demais produtos, pois seu desconto é efetuado direto em folha, sendo exceção à regra de impenhorabilidade do antigo artigo 649 inciso IV e atual 833 com igual inciso, do Código de Processo Civil.

O Decreto-lei 8.690 de 2016 restringe a utilização de até 35\% (trinta e cinco por cento) do soldo com o total de parcelas consignadas, reservando $5 \%$ (cinco por cento) apenas para o cartão consignado. A limitação pretende resguardar os direitos da família, da subsistência digna e o mínimo existencial, pois, mesmo já havendo previsão legal sobre os direitos individuais, se deu a necessidade de positivá-los novamente.

Existem, ainda, outras manifestações legais sobre o percentual a ser ocupado na remuneração dos clientes:

Art. 45. Salvo por imposição legal, ou mandado judicial, nenhum desconto incidirá sobre a remuneração ou provento.

[...] § $2^{\circ} \mathrm{O}$ total de consignações facultativas de que trata $\circ \S 1^{\circ}$ não excederá a $35 \%$ (trinta e cinco por cento) da remuneração mensal, sendo 5\% (cinco por cento) reservados exclusivamente para: (Redação dada pela Lei no 13.172, de 2015)

I - a amortização de despesas contraídas por meio de cartão de crédito; ou (Incluído pela Lei no 13.172, de 2015)

II - a utilização com a finalidade de saque por meio do cartão de crédito. (Lei no 8.112, de 11 de dezembro de 1990)

Art. 115. Podem ser descontados dos benefícios:

[...] VI - pagamento de empréstimos, financiamentos, cartões de crédito e operações de arrendamento mercantil concedidos por instituições financeiras e sociedades de arrendamento mercantil, ou por entidades fechadas ou abertas de previdência complementar, públicas e privadas, quando expressamente autorizado pelo beneficiário, até o limite de $35 \%$ (trinta e cinco por cento) do valor do benefício, sendo 5\% (cinco por cento) destinados exclusivamente para: (Redação dada pela Lei no 13.183, de 2015)

a) amortização de despesas contraídas por meio de cartão de crédito; ou (Redação dada pela Lei no 13.183, de 2015)

b) utilização com a finalidade de saque por meio do cartão de crédito. (Lei no 8.213, de 24 de julho de 1991) 
Art. $1^{\circ}$ Os empregados regidos pela Consolidação das Leis do Trabalho CLT, aprovada pelo Decreto-Lei no 5.452, de 1어 de maio de 1943, poderão autorizar, de forma irrevogável e irretratável, o desconto em folha de pagamento ou na sua remuneração disponível dos valores referentes ao pagamento de empréstimos, financiamentos, cartões de crédito e operações de arrendamento mercantil concedidos por instituições financeiras e sociedades de arrendamento mercantil, quando previsto nos respectivos contratos. (Redação dada pela Lei no 13.172, de 2015)

$\S 1^{\circ}$ 을 desconto mencionado neste artigo também poderá incidir sobre verbas rescisórias devidas pelo empregador, se assim previsto no respectivo contrato de empréstimo, financiamento, cartão de crédito ou arrendamento mercantil, até o limite de 35\% (trinta e cinco por cento), sendo 5\% (cinco por cento) destinados exclusivamente para: (Redação dada pela Lei no 13.172, de 2015)

I - a amortização de despesas contraídas por meio de cartão de crédito; ou (Incluído pela pela Lei no 13.172, de 2015)

II - a utilização com a finalidade de saque por meio do cartão de crédito. (Incluído pela pela Lei $n=13.172$, de 2015) (Lei $\mathbf{n}^{0} \mathbf{1 0 . 8 2 0}$, de 17 de dezembro de 2003)

Art. 2 - Entendem-se por consignações os descontos mensais realizados sobre os valores percebidos mensalmente a título de vencimentos, salários, soldos, proventos e nas pensões.

$\S 1$ ㅇ - Para os fins deste decreto, considera-se:

[...] 5. margem consignável: percentual correspondente a 30\% (trinta por cento) aplicável sobre a parcela dos vencimentos, salários, soldos, proventos e pensões percebidas no mês, compreendendo o padrão de vencimentos acrescido das vantagens pecuniárias que a ele se integram nos termos da lei ou de outros atos concessivos, as vantagens incorporadas, os adicionais de caráter individual, bem assim as vantagens pessoais ou as fixadas para o cargo de forma permanente por legislação específica, com a dedução dos descontos obrigatórios. (Decreto no 60.435, de 13 de maio de 2014)

Quando o banco excede tal limite, ele já apresenta aspecto desfavorável no julgamento do caso concreto, haja vista, estar agindo contra legem. No entanto, é válido destacar que a boa-fé, como requisito indispensável no acordo de vontades, deve ser reconhecida tanto no sujeito ativo, quanto no passivo. Assim, o devedor não poderá desfrutar de vantagem indevida com a procedência do seu pleito, pois deverá ser analisada a possibilidade que ele tinha de conhecer ou planejar o resultado de suas ações.

Cabe ainda aduzir que presume-se como verdadeiro e impensado o superendividamento, restando ao outro polo da ação a função de provar a possibilidade de ciência e até programação do inadimplente frente ao narrado, ou seja, o ônus da prova se inverterá. Procedimento que prenuncia o caráter próprio de relação consumerista (Súmula 297 do STJ). 
Outra peculiaridade do instituto descrita no conceito corresponde à quem poderá desfrutá-lo. Por razões óbvias, somente a pessoa física pode se valer do sobredito, posto que, se sua incidência fosse estendida à pessoa jurídica não haveria direito falimentar.

A sentença que versar sobre a procedência ou não da ação revisional do contrato bancário deve caminhar sobre a linha tênue da real necessidade de alteração das condições fixadas e o reconhecimento da má-fé do consumidor que conhecedor dos possíveis resultados de seus atos, não se precaveu e, agora, tenta gozar de vantagem indevida. Destarte, o objetivo inicial do dispositivo deve ser mantido, qual seja, moderar imposições contratuais que por fato futuro tornaram-se excessivamente onerosas, identificando ou reestabelecendo a boa-fé. 0 desembargador cuja sentença segue teve o zelo de vislumbrar a responsabilidade dos dois polos, reformando o pacto, sem onerá-los. Portanto, foi retomada a equidade da relação.

Apelação - Ação revisional cumulada com indenizatória. Superendividamento. Descontos em folha de pagamento relativos a empréstimos contratados, que comprometem a quase totalidade dos vencimentos da parte autora. $\mathbf{O}$ salário traduz verba alimentar e deve ser preservado um mínimo de recursos que possibilite a subsistência do devedor (CPC, art. 649, IV), sob pena de ofensa à dignidade da pessoa humana (CF/88, art. 1ㅇ, III). Retenção mensal que deve ser limitada a $\mathbf{3 0 \%}$ dos vencimentos do autor. SENTENÇA DE PARCIAL PROCEDÊNCIA. Aplicação dos verbetes 200 e 295, da Súmula deste TJRJ. RECURSO QUE PLEITEIA A REFORMA DE PARTE DO DECISUM QUE JULGOU IMPROCEDENTE O PEDIDO DE INDENIZAÇÃO POR DANOS MORAIS. HIPÓTESE DE FATO DA VÍTIMA QUE, POR SUA PRÓPRIA INCAPACIDADE DE GERIR SUAS FINANÇAS, GEROU SEU SUPERENDIVIDAMENTO, O QUE AFASTA O DEVER DE INDENIZAÇÃO POR DANOS MORAIS. RECURSO A QUE SE NEGA SEGUIMENTO, NOS TERMOS DO ART. 557, CAPUT, DO CPC. (Grifos nossos) (RIO DE JANEIRO, TJ-RJ - Apelação APL 00013466520038190037 RJ 0001346-65.2003.8.19.0037- Data de publicação: 18/09/2015)

Inicialmente, vale ressaltar que além de estabilizar a desavença, o retorno da averbação dos consignados ao patamar legalmente permitido também pune a conduta irregular do agente financeiro.

Como visto, a forma encontrada para solucionar o problema fora um remédio jurídico popular: a ponderação de princípios. Ora, a dignidade da pessoa humana, a equidade e a boa-fé, se sopesadas com a "rigidez" do acordo, devem prevalecer, como no exemplo:

[...] em contrato de adesão, como é o caso do consórcio firmado, são nulas as cláusulas abusivas (art. 51, Lei 8.078/90), dentre as quais aquelas que coloquem o consumidor em desvantagem exagerada (inciso IV do mesmo artigo), estejam em desacordo com o sistema de proteção ao consumidor (inciso XV), se mostre 'excessivamente onerosa para o consumidor, considerando-se a natureza e conteúdo do contrato, o interesse das partes e outras circunstâncias peculiares ao caso' (§ 10, inciso III, artigo 51) e ofenda os princípios fundamentais do CDC (§ 10, inciso I, do mesmo artigo 51). Dentre esses princípios está a boa-fé (artigo 40, III), que é também 
condição geral dos contratos (art. 51, IV). E essa boa-fé é objetiva, presumida como regra de conduta nas relações de consumo. (NUNES, 2014, p. 714)

Nunes (2015, p. 726) assim interpretou a utilização do princípio da boa-fé na confecção das sentenças:

Dessa maneira percebe-se que a cláusula geral de boa-fé permite que o juiz crie uma norma de conduta para o caso concreto, atendo-se sempre à realidade social, o que nos remete à questão da equidade, prevista ao final da norma em comento.

Através da abordagem desse autor tem-se que a decisão variará conforme o caso concreto, restando a quem "diz o Direito" considerar uma conduta aceitável para o questionamento em tela, por meio da busca pelo equilíbrio das prestações de ambas partes.

Já noutro momento, a taxatividade do contrato reinará. $\mathrm{O}$ acórdão abaixo exemplifica:

Direito civil. Revisional. Contrato de empréstimo consignado. Desconto de parcelas de mútuo bancário em folha de pagamento. Margem consignável. Limitação ao percentual de $30 \%$. Capitalização mensal de juros. Tabela price. Legalidade. 1. O desconto de prestações de empréstimos consignados em folha de pagamento não devem exceder o limite legal de $30 \%$ (trinta por cento) da remuneração (Decreto $6.386 / 08$ ), de modo a não comprometer a subsistência do servidor. 2. Incabível a alegação de utilização excessiva da margem consignável, quando o empréstimo questionado antecedeu a contratação de outros com instituições financeiras diversas, na tentativa de impor à primeira contratada a redução da parcela do mútuo. 3. É permitida a aplicação da Tabela Price em contrato de empréstimo consignado, em face da admissão da capitalização mensal de juros. 4 - Recurso conhecido e improvido. (Grifos nossos) (BRASÍLIA, TJ-DF, Apelação Cível APC 20140110743740 DF 0017656-10.2014.8.07.0001 - Data de publicação: 06/03/2015)

Na página do Banco Central há a informação de que é ilimitado os juros das operações, com raras ressalvas, dentre elas o financiamento habitacional cuja taxa não pode superar $12 \%$ a.a. (doze por cento ao ano) mais Taxa Referencial. Portanto, a alegação de que, no país, os juros destoam do razoável, ganha respaldo. Opostamente, se não há limitador, não deverão as instituições serem punidas por esse fato: trata-se do trivial conceito de legalidade. Entretanto, reprisa-se o argumento: os juros que implicarem em desvantagem excessiva para o consumidor podem ser protestados, conforme decidido abaixo:

Direito processual civil e bancário. Recurso especial. Ação revisional de cláusulas de contrato bancário. Incidente de processo repetitivo. Juros remuneratórios. Configuração da mora. Juros moratórios. Inscrição/manutenção em cadastro de inadimplentes. Disposições de ofício. Delimitação do julgamento. [...] Julgamento das questões idênticas que caracterizam a multiplicidade. Orientação 1 - Juros remuneratórios: a) 
As instituições financeiras não se sujeitam à limitação dos juros remuneratórios estipulada na Lei de Usura (Decreto n. 22.626/1933), Súmula n. 596/STF; b) A estipulação de juros remuneratórios superiores a $12 \%$ ao ano, por si só, não indica abusividade; c) São inaplicáveis aos juros remuneratórios dos contratos de mútuo bancário as disposições do art. 591, c/c o art. 406 do CC/2002; d) É admitida a revisão das taxas de juros remuneratórios em situações excepcionais, desde que caracterizada a relação de consumo e que a abusividade (capaz de colocar o consumidor em desvantagem exagerada art. 51, $\S 10$, do $C D C$ ) fique cabalmente demonstrada, ante as peculiaridades do julgamento em concreto. Orientação 2 - Configuração da mora: a) 0 reconhecimento da abusividade nos encargos exigidos no período da normalidade contratual (juros remuneratórios e capitalização) descaracteriza a mora; b) Não descaracteriza a mora o ajuizamento isolado de ação revisional, nem mesmo quando o reconhecimento de abusividade incidir sobre os encargos inerentes ao período de inadimplência contratual. Orientação 3 - Juros moratórios: Nos contratos bancários, não regidos por legislação específica, os juros moratórios poderão ser convencionados até o limite de $1 \%$ ao mês. [...] (Grifos nossos) (BRASílIA, STJ, 2a Seção, REsp 1.061.530-RS, Rel. Min. Nancy Andrighi, j. 22.10.2008).

Objetiva-se com a repulsa a onerosidade excessiva o reestabelecimento do equilíbrio contratual, justificando o princípio da equidade. Logo, as decisões devem estar consolidadas naquilo que as partes desejavam no ato da contratação, podendo o instrumento ser revisto e até mesmo, alterado.

O governo através de seu poder coercitivo tem imputado aos bancos o dever de oferecimento de alternativas para renegociação frente ao crescimento da inadimplência, ou seja, facilitar o processo. E, também, decidiu reduzir os juros do rotativo do cartão de crédito e do consignado. Dentre as mais interessantes interferências, surge a possibilidade de pausar o pagamento do contrato de financiamento habitacional por determinado período, na Caixa Econômica Federal, quando o titular estiver desempregado. A iniciativa também preserva o bem de família, sendo ele, majoritariamente, o objeto dos contratos habitacionais.

\section{CONCLUSÃO}

Por todo o exposto, revela-se que o positivismo contratual se faz antiquado quando confronta com os direitos individuais, inclusive nos contratos bancários.

Logo, quando um acordo apresenta alterações veementes, capazes de corromper seu objetivo inicial de modo a sobrecarregar um dos interessados, se configura a onerosidade excessiva. Tal consequência afasta o pleno gozo da "dignidade da pessoa humana" e a execução do princípio da equidade. Assim como é esperado noutras espécies contratuais, poderá haver a revisão do contrato estudado, para que os anseios dos contratantes sejam atendidos.

O superendividamento é um fenômeno que excede as vias econômicas, revelando um padrão social de consumismo, gastos acima dos ganhos, incentivo a compra, desaguando na aquisição de financiamentos, dentre outras formas de crédito. Ele configura hipótese de alteração contratual, se presentes os demais critérios além da cumulação de débitos, quais sejam: pessoa física, leiga e de boa-fé que, se continuar adimplindo as obrigações, não desfrutará do mínimo existencial, por tão penosa situação a que estará submetido. 
Ademais, a tomada de providência é necessária, posto que, em regra, a fonte dos descontos é a folha de pagamento ou a conta do prejudicado e dependendo do percentual do abatimento, a sobrevivência do devedor se torna impraticável. A remuneração pelo trabalho, além das oportunidades secundárias, permite a subsistência, abrangendo despesas com alimentos, educação e saúde. Conclui-se que o ser humano se sobressai ao patrimônio. Por óbvio, o contratado deverá ser adimplido, no entanto, de um modo que circunde o razoável que variará caso a caso.

Todavia, a aferição das provas e a análise do caso deve ser realizada de modo que não haja imposição de sanção indevida ao fornecedor, v.g., movimentando a reprovada "máquina do danomoral". Sobretudo, quando o devedor, originariamente, agia de má-fé, carecendo assim, do desconhecimento: requisito fundamental à inserção no instituto. $E$, ainda, as decisões não devem ser desarrazoadas aparentando instaurar o regime da insegurança jurídica.

Enfim, como o próprio Direito, a resposta para a problematização proposta varia, sendo moldada ao caso concreto pelo arcabouço judicial que o juiz dispõe e, mormente, pelos princípios.

\section{REFERÊNCIAS BIBLIOGRÁFICAS}

BRASIL. Código civil. Brasília, DF: Senado, 2002. Disponível em: <http://www.planalto.gov.br/ccivil_03/leis/2002/L10406.htm>. Acesso em: 01 jun. 2017.

BRASIL. Código de defesa do consumidor. Brasília, DF: Senado, 1990. Disponível em: <http://www.planalto.gov.br/ccivil_03/leis/L8078.htm>. Acesso em: 01 jun. 2017.

BRASIL. Código de processo civil. Brasília, DF: Senado, 2015. Disponível em: <http://www.planalto.gov.br/ccivil_03/_ato2015-2018/2015/lei/l13105.htm>. Acesso em: 01 jun. 2017.

BRASIL. Constituição (1934). Constituição da República Federativa do Brasil. Brasília, DF: Senado, 1934.

BRASIL. Constituição (1988). Constituição da República Federativa do Brasil. Brasília, DF: Senado, 1988.

BRASIL. Decreto-lei n.o 8.690, de 11 de março de 2016. Dispõe sobre a gestão das consignações em folha de pagamento no âmbito do sistema de gestão de pessoas do Poder Executivo federal. Diário Oficial da República Federativa do Brasil. Brasília, DF, 14 mar. 2016. Disponível em: <http://www.planalto.gov.br/ccivil_03/_Ato2015-2018/2016/Decreto/D8690.htm\#art14>. Acesso em: 15 jun. 2017.

BRASIL. Decreto-lei n.o 22.626, de 7 de abril de 1933. Dispõe sobre os juros nos contratos e dá outras providencias. Coleção das Leis do Império do Brasil. Brasília, DF, 7 abr. 1933. Disponível em: < http://www.planalto.gov.br/ccivil_03/decreto/d22626.htm>. Acesso em: 15 jun. 2017.

BRASIL. Lei n.o 8.112, de 11 de dezembro de 1990. Dispõe sobre o regime jurídico dos servidores públicos civis da União, das autarquias e das fundações públicas federais. Diário Oficial da República Federativa do Brasil. Brasília, DF, 19 abr. 1991. Disponível em: <http://www.planalto.gov.br/ccivil_03/leis/L8112cons.htm>. Acesso em: 15 jun. 2017. 
BRASIL. Lei n.o 8.213, de 24 de julho de 1991. Dispõe sobre os Planos de Benefícios da Previdência Social e dá outras providências. Diário Oficial da República Federativa do Brasil. Brasília, DF, 25 jul. 1991. Disponível em: <http://www.planalto.gov.br/ccivil_03/leis/L8213cons.htm>. Acesso em: 15 jun. 2017.

BRASIL. Lei n.o 10.820, de 17 de dezembro de 2003. Dispõe sobre a autorização para desconto de prestações em folha de pagamento. Diário Oficial da República Federativa do Brasil. Brasília, DF, 18 dez. 2003. Disponível em: <http://www.planalto.gov.br/ccivil_03/leis/2003/L10.820.htm>. Acesso em: 17 dez. 2003.

BRASIL. Superior Tribunal de Justiça. Súmula n.o 297. O Código de Defesa do Consumidor é aplicável às instituições financeiras. Disponível em: <https://ww2.stj.jus.br/docs_internet/revista/eletronica/stj-revista-sumulas2011_23_capSumula297.pdf>. Acesso em: 14 jun. 2017.

BRASÍlIA. Tribunal de Justiça. Apelação - Direito civil. Revisional. Contrato de empréstimo consignado. Desconto de parcelas de mútuo bancário em folha de pagamento. Margem consignável. Limitação ao percentual de 30\%. Capitalização mensal de juros. Tabela price. Legalidade.

Apelação Cível APC 20140110743740 DF 0017656-10.2014.8.07.0001. Maria das Graças Leite e Banco Cruzeiro do Sul S/A. Relator: Leila Arlanch. Rio de Janeiro, 25 de fevereiro de 2015, Data de Publicação: 06/03/2015. 2a Turma Cível. Pág.: 274. Site do Jusbrasil. Disponível em: <https://tjdf.jusbrasil.com.br/jurisprudencia/172093798/apelacao-civel-apc-20140110743740-df-00176561020148070001/inteiro-teor-172093838>. Acesso em: 01 jun. 2017.

BRASÍLIA. Superior Tribunal de Justiça. Recurso Especial - Direito processual civil e bancário. Recurso especial. Ação revisional de cláusulas de contrato bancário. Incidente de processo repetitivo. Juros remuneratórios. Configuração da mora. Juros moratórios. Inscrição/manutenção em cadastro de inadimplentes. Disposições de ofício. Delimitação do julgamento. [...] Julgamento das questões idênticas que caracterizam a multiplicidade. [...] REsp 1.061.530-RS. UNIBANCOUnião De Bancos Brasileiros S/A e Rosemari Dos Santos Sanches. Relator: Ministra Nancy Andrighi. Brasília, 22 de outubro de 2008. 2a Seção, Data de Publicação: 10/03/2009. Site do Jusbrasil. Disponível em: <https://stj.jusbrasil.com.br/jurisprudencia/2438811/recurso-especial-resp1061530-rs-2008-0119992-4>. Acesso em: 02 jun. 2017.

CÁRNIO, Thaís Cíntia. Dicionário jurídico de termos contratuais: inglês - português. São Paulo: Atlas, 2010, p. 94

CUNHA, Sérgio da. Dicionário Compacto do Direito. 10. ed. São Paulo: Saraiva, 2011, p. 290 - 291.

FAQ - Empréstimos e financiamentos. Site do Banco Central do Brasil. Brasília - DF. Disponível: <http://www.bcb.gov.br/pre/bc_atende/port/servicos9.asp\#7>. Acesso: em 15 jun. 2017.

GOVERNO reduz juros do consignado para servidores e segurados do INSS: Portaria do Ministério do Planejamento reduz, pela primeira vez, o teto de juros cobrado nas operações de empréstimo consignado. Site do Portal Brasil. Brasília - DF. Seção Economia e Emprego. Disponível em: 
<http://www.brasil.gov.br/economia-e-emprego/2017/04/governo-reduz-juros-do-consignadopara-servidores-e-segurados-do-INSS>. Acesso em: 15 jun. 2017.

LIMA, Roberto Arruda Souza; NISHIYAMA, Mamoru. Contratos bancários: aspectos jurídicos e técnicos da matemática financeira para advogados. São Paulo: Atlas, 2007.

LÔBO, Paulo. Direito civil: obrigações, 4. ed. São Paulo: Saraiva, 2015.

MACHADO, Antônio Cláudio da (org.); FERRAZ, Anna Candida da (coord.). Constituição Federal Interpretada: Artigo por Artigo, Parágrafo por Parágrafo. 6. ed. Barueri: Manole, 2015.

NASSER, Paulo Magalhães. Onerosidade excessiva no Contrato Civil. 1. ed. São Paulo: Saraiva, 2011.

NUNES, Rizzatto. Comentários ao Código de Defesa do Consumidor. 8. ed. São Paulo: Saraiva, 2014.

PINHO, Rodrigo Rebello. Col. Sinopses jurídicas 18: Da organização do Estado, dos poderes e histórico das constituições. 15. ed. São Paulo: Saraiva, 2015.

RIO DE JANEIRO. Tribunal de Justiça. Apelação - Ação revisional cumulada com indenizatória. Superendividamento. Recurso a que se nega seguimento, nos termos do art. 557, caput, do cpc. Apelação APL 00013466520038190037 RJ 0001346-65.2003.8.19.0037. Marcia Alves Pena e Banco Do Brasil S/A. Relator: Des. Jose Acir Lessa Giordani. Rio de Janeiro, 15 de setembro de 2015, Vigésima Quinta Câmara Cível/ CONSUMIDOR, Data de Publicação: 18/09/2015. Site do Jusbrasil. Disponível em: <https://tjrj.jusbrasil.com.br/jurisprudencia/236655363/apelacao-apl-13466520038190037-rj-00013466520038190037/inteiro-teor-236655387?ref=juris-tabs>. Acesso em: 20 jun. 2017.

ROCHA. Juliana. Endividamento cresce 47\% em 26 meses. Folha online. 23/06/2008. Disponível em: <http://www1.folha.uol.com.br/folha/dinheiro/ult91u414905.shtml> Acesso em: 15 de maio de 2017.

SANTOS, Brenda Schneider dos. 0 superendividamento e o controle do empréstimo consignado. 2008. 41 f. Monografia (Bacharelado em Direito) - Faculdade de Direito da Pontifícia Universidade Católica do Rio Grande do Sul, Porto Alegre, 2008. Disponível em: <http://www3.pucrs.br/pucrs/files/uni/poa/direito/graduacao/tcc/tcc2/trabalhos2008_2/brenda_ schneider.pdf>. Acesso em: 20 maio 2017.

SÃO PAULO. Decreto n.o 60.435, de 13 de maio de 2014. Dispõe sobre as consignações em folha de pagamento de servidores públicos civis e militares, ativos, inativos e reformados e de pensionistas da administração direta e autárquica e dá providências correlatas. Diário Oficial do Estado de São Paulo. São Paulo, SP, 14 maio 2014. Disponível em: <http://www.al.sp.gov.br/repositorio/legislacao/decreto/2014/decreto-60435-13.05.2014.html>. Acesso em: 19 jun. 2017. 
SCHONBLUM, Paulo Maximilian Mendlowicz. Contratos Bancários. 4. ed. Rio de Janeiro: Forense, 2015.

TARTUCE, Flávio. Direito Civil - Vol. 3 - Teoria Geral dos Contratos em Espécie, 11. ed. Rio de Janeiro: Forense, 2015. 